\title{
FUT4 wt Allele
}

National Cancer Institute

\section{Source}

National Cancer Institute. FUT4 wt Allele. NCI Thesaurus. Code C104401.

Human FUT 4 wild-type allele is located in the vicinity of $11 \mathrm{q} 21$ and is approximately $6 \mathrm{~kb}$ in length. This allele, which encodes alpha-(1,3)-fucosyltransferase 4 protein, plays a role in the generation of fucosylated carbohydrate structures. 